\title{
Mass movements in the Rio Grande Valley (Quebrada de Humahuaca, Northwestern Argentina): a methodological approach to reduce the risk
}

\author{
G. Marcato ${ }^{1}$, A. Pasuto ${ }^{1}$, and F. R. Rivelli ${ }^{2}$ \\ ${ }^{1}$ CNR-IRPI - National Research Council of Italy, Research Institute for Hydrological and Geological Hazard Prevention, \\ C. so Stati Uniti 4, 35127 Padova, Italy \\ ${ }^{2}$ Departamento de Ciencias Naturales, Universidad Nacional de Salta, Casilla De Correo 529, 4400 Salta, Argentina
}

Received: 9 June 2009 - Revised: 24 August 2009 - Accepted: 25 August 2009 - Published: 13 October 2009

\begin{abstract}
Slope processes such as slides and debris flows, are among the main events that induce effects on the Rio Grande sediment transport capacity. The slides mainly affect the slope of the Rio Grande river basin while debris and mud flows phenomena take place in the tributary valleys. In the past decades several mass movements occurred causing victims and great damages to roads and villages and therefore hazard assessment and risk mitigation is of paramount importance for a correct development of the area. This is also an urgent need since the Quebrada de Humahuaca was recently included in the UNESCO World Cultural Heritage. The growing tourism business may lead to an uncontrolled urbanization of the valley with the consequent enlargement of threatened areas.

In this framework mitigation measures have to take into account not only technical aspects related to the physical behaviour of the moving masses but also environmental and sociological factors that could influence the effectiveness of the countermeasures.

Mitigation of landslide effects is indeed rather complex because of the large extension of the territory and the particular geological and geomorphological setting. Moreover the necessity to maintain the natural condition of the area as prescribed by UNESCO, make this task even more difficult.

Nowadays no in-depth study of the entire area exists, therefore an integrated and multidisciplinary investigation plan is going to be set up including geological and geomorphological investigations as well as archaeological and historical surveys. The better understanding of geomorphological evolution processes of the Quebrada de Humahuaca
\end{abstract}

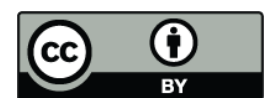

Correspondence to: G. Marcato (marcato@irpi.cnr.it) will bridge the gap between the necessity of preservation and the request of safety keeping of the recommendation by UNESCO.

\section{Introduction}

The Rio Grande flows in a narrow mountain valley located in the Province of Jujuy in northwest Argentina, some $1500 \mathrm{~km}$ north-west of Buenos Aires. This valley, named Quebrada de Humahuaca (QdH), follows the line of a major cultural route, the Camino Inca, from the Rio Grande springs in the cold high desert plateau of the High Andean lands, to its confluence with the Rio Leone some $150 \mathrm{~km}$ to the south. It has provided a natural route for people to travel from the time of hunters and gatherers right to the present day. For this reason it has been included in the UNESCO Word Heritage since 2003.

There are almost 20 hamlets along the valley, but the population is dramatically shrinking due to the high frequency of mass movements that cause relevant damages to the Ruta Panamericana Nacional n. 9, connecting Argentina with Chile and Bolivia, and the Ferrocarril General Belgrano. This strategic railway was completely abandoned in 1992 due to high maintenance costs. Moreover, these mass movements cause serious damages also to the farming activities along the valley floor actually reducing the land available to be cultivated and therefore the possibility of sustenance of the population.

Landslides and debris flows are thus the main hazardous phenomena affecting the slopes and inducing serious consequences on the erosion and sedimentation activity of the Rio Grande (Cencetti et al., 2001). A great amount of loose

Published by Copernicus Publications on behalf of the European Geosciences Union. 
debris is available due to the geological and lithotechnical characteristics of the outcropping geologic units and this induces a dangerous situation for the infrastructures and the population.

Nowadays, an in-depth study of the entire area is still not available, therefore an integrated and multidisciplinary investigation plan is going to be set up.

The research activity should include geological and geomorphological investigations as well as archaeological and historical surveys. Moreover, social and economical aspects have to be considered in order to assess the impact of mitigation measures on the urban and anthropic environment.

\section{Physical setting}

The Quebrada de Humahuaca is included in the ridge-andvalley system with a $\mathrm{N}-\mathrm{S}$ direction, characterizing the eastern Cordillera Andina. Its outlet is located close to San Juan de Jujuy. The valley represents a strategic route connecting Argentina to Chile and Bolivia (Fig. 1). It is crossed by the Rio Grande, which is characterized by a variable discharge due to extreme climatic variability, either in space and in time. The historic time series of river discharge is short and discontinuous (from 1940 to 1945 and 1951 to 1954). The station of San Juan is located some $180 \mathrm{~km}$ downstream from the springs, and the basin extends for $7650 \mathrm{~km}^{2}$. It has an average width of $300 \mathrm{~m}$ and a slope of $1.30 \%$. The mean daily discharge varied from 16.4 and $24.7 \mathrm{~m}^{3} \mathrm{~s}$. The maximum discharge was $358 \mathrm{~m}^{3} \mathrm{~s}$ and the minimum was $3 \mathrm{~m}^{3} \mathrm{~s}$.

The elevation of the valley bottom ranges from $3440 \mathrm{~m}$ a.s.l. in the vicinity of the village of Iturbe to $1350 \mathrm{~m}$ in correspondence to its confluence to Rio Reyes; the total length is about $144 \mathrm{~km}$ and its width ranges from $100 \mathrm{~m}$ up to $3 \mathrm{~km}$ close to the village of Tilcara. The valley is bounded by the Sierra Zenta-Tilcara eastward, that reaches the elevation of $5100 \mathrm{~m}$ and the Sierra Agular and Chani, westward exceeding $6200 \mathrm{~m}$. Therefore, the differences in elevation are very pronounced and strongly influence the distribution of precipitations.

From the climatic point of view, the valley is characterized by a sub-tropical regime in its southernmost part, with an average yearly rainfall of more than $400 \mathrm{~mm}$, whereas the central part, between the hamlets of Tilcara and Humahuaca, is dryer and can be considered a semi-arid environment. This is also due to the great differences in elevation between the valley bottom and the surrounding peaks.

The synthesis of the monthly rainfall in the period 19341990 is given in Fig. 1, where the total lack of precipitation during winter and the summer peak can be observed.

Rainfall data recorded in the period 1934-1990 shows an average of $391 \mathrm{~mm} / \mathrm{yr}$ in Volcan, with a maximum of $719 \mathrm{~mm}$ in 1963, and a minimum of $123 \mathrm{~mm}$ during 1940 . With reference to the same period, average values lower than $200 \mathrm{~mm}$ have been recorded in Tilcara-Humahuaca (136 and
$175 \mathrm{~mm} / \mathrm{yr}$, respectively). The amount of rainfall increases northward, in the Puna Jujena region, with $282 \mathrm{~mm} / \mathrm{yr}$ in Abra Pampa up to $335 \mathrm{~mm} / \mathrm{yr}$ in La Quiaca, near to the Bolvian border.

The mean annual temperature in the central part of the valley, near Humahuaca, for the period 1961-1970, is of the order of $12^{\circ} \mathrm{C}$. Southward, in Hornillos, it reaches $14^{\circ} \mathrm{C}$, whereas in the northern areas (La Quiaca), the average value lowers to $9.2^{\circ} \mathrm{C}$, because of the higher altitudes. The thermal regime is anyway characterized by significant variations on a daily basis, with differences that can reach $40^{\circ} \mathrm{C}$.

This thermal regime plays the major role in the production of debris at the foot of slopes, that is made available and mobilized during debris flow and flood events.

The Rio Grande, while crossing the $\mathrm{QdH}$, receives the waters of right hand tributaries, such as the Reyes, Leon Purmamarca and Yacoraite streams. Most of these streams originate from springs located at altitudes in the order of $4000 \mathrm{~m}$, where permanent glaciers guarantee an outflow during the whole year.

\section{Geological and geomorphological outlines}

The geological and structural features of the Quebrada de Humahuaca are relatively simple: from the valley bottom up to the western ridge, Precambrian and Cambrian units prevail. The first belongs to the Puncoviscana Formation, a low grade metamorphic unit with greywacke; it is characterized by a one thousand meters thickness an intense and diffuse fracturing. The Cambrian rocks, belonging to the Meson group, which is itself divided into three subunits, constitute the principal core of the ridge (sierra). These are mainly multicolored orthoquarzites and quarz-rich arenites (Ramos et al., 1967; Turner, 1970; Amegual and Zanettini, 1974).

Over these units, an extensive Quaternary cover is found, which was generated by gravity processes acting in the upper part of the slopes together with debris flows and alluvial phenomena in the valley bottom. Mass wasting phenomena are also conditioned by the notable tectonic uplift of the area (Chayle et al., 1987).

The general morphology is related to the presence of a homoclinal, with N-S direction dipping eastward. Regional N$\mathrm{S}$ faults have produced the uplift of large areas and determined the development and incision of N-S valleys, such as the Quebrada de Humahuaca (Turner, 1970; Mon and Salfity, 1995).

The morphology of this area is strictly controlled by the lithological features of the rock masses and by ancient and active tectonics. The landscape is characterized by a significant asymmetry of the valley flanks which in turn conditions the type and activity of the processes and the landforms.

On the eastern flank two terraces formed by Rio Grande can be found, together with huge incised alluvial fans generated by the different tributaries originating from the eastern 


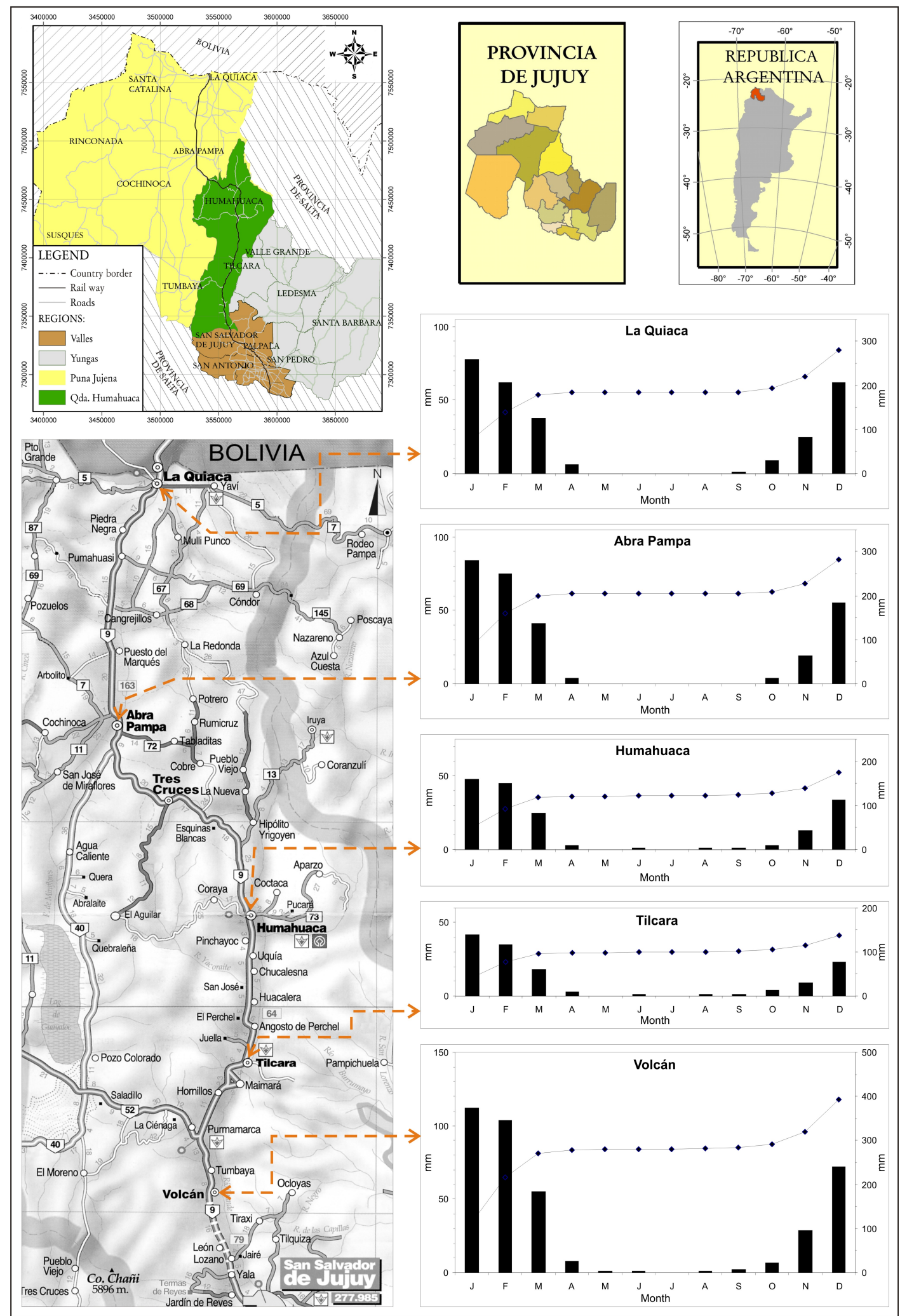

Fig. 1. Location map of Northwest Argentina. The Quebrada de Humahuaca stretches across the Tropic of Capricorn. Monthly rainfall in the period 1934-1990 in the Quebrada de Humauaca and Puna Jujena Regions. Data are derived from the National Meteorological Survey and from the Ferrocaril General Belgrano. Main roads, including Ruta Nacional n. 9 Panamericana, are indicated on the map. 


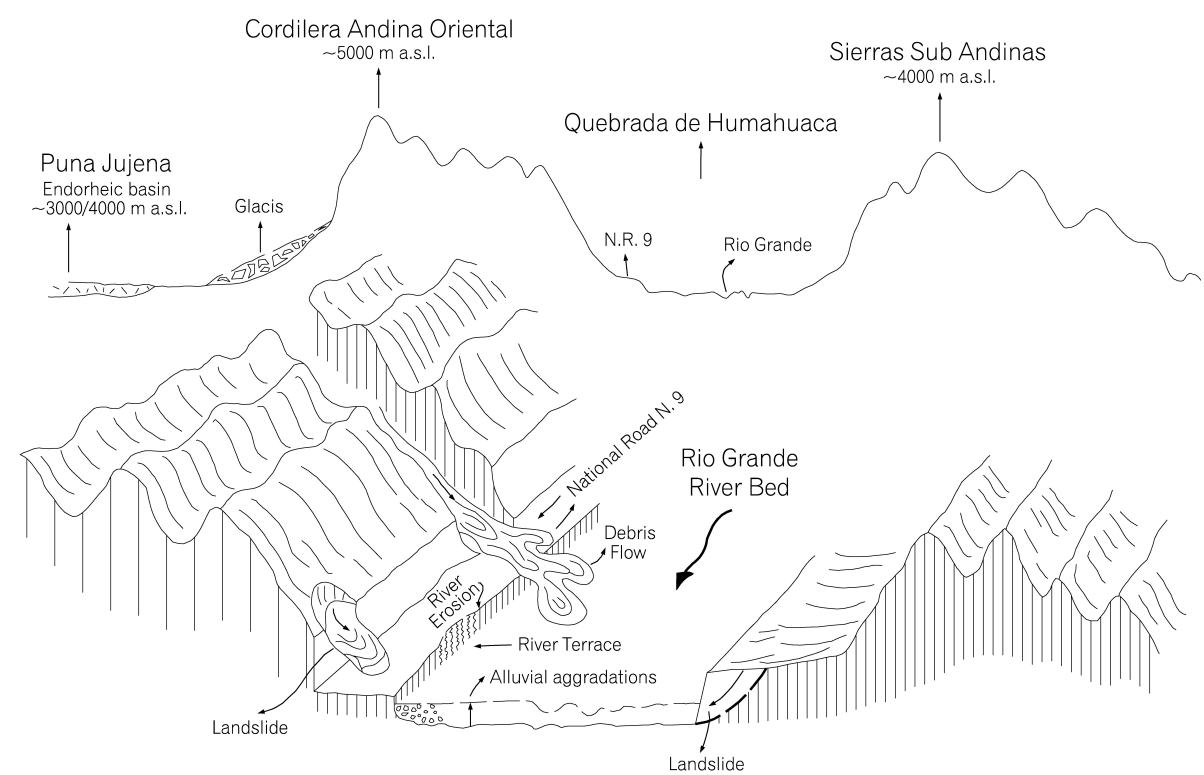

Fig. 2. Sketch of the main geomorphological processes and landforms active in the Quebrada de Humahuaca at present.

cordillera. The present-day geomorphological evolution of the Quebrada de Humahuaca is largely controlled by the mobilization of the thick deposits generated by the physical weathering of the rock masses. The presence of a large amount of debris facilitates debris flow and hyperconcentrated flow phenomena, that lead to the aggradations of the Rio Grande watercourse. The Ruta Nacional n. 9 is involved in some small landsliding phenomena (Fig. 2).

\section{Main hazard factors and risk implications}

As pointed out by the description of the geomorphological evolution, the main processes in the Quebrada de Humahuaca are related to mass transport, that originates from the right hand side tributaries, and to erosional and depositional processes related to the Rio Grande fluvial system.

Under the present morphoclimatic context, these predisposing factors lead to extensive alluvial phenomena at the outflow of the tributary valleys and in the main valley floor, where large alluvial fans have occasionally determined the partial or total damming of the river, as it can be observed in the area of El Volcan. In the recent past, some of these fans have been exploited as preferential areas for hamlets and houses, with subsequent risk conditions posed to population. Apart from the risk posed to the inhabited areas in the vicinity of streams, a further consequence of alluvial phenomena is the progressive reduction of agricultural lands.

It is interesting to analyze the sedimentary sequences outcropping along the Rio Grande valley since they highlight an almost systematic recurrence of mass movements. Unfortunately no radiometric datings are available at present so that it is not possible to define frequency and return time, but it can be stated that no alluvial phenomena involving the entire valley occurred in the last centuries. This is mainly due to the particular distribution of the rainfall that is strictly controlled by the relief and difference in elevation. It is rather common to register heavy rainfall on the east slope and dry conditions on the opposite. It follows that the occurrence in time and space of debris flows and other mass movements is quite random and unpredictable.

Nevertheless, several catastrophic events, causing economic losses and also victims, occurred in the last decades. Noteworthy is the debris flow that occurred in 1983 in the Rio Huasamayo river basin. It involved the village of Tilcara overflooding the cultivated fields and the camping area where two tourists lost their life. The estimated volume was of the order of some million of cubic meters and the deposits dammed the Rio Grande valley, causing the formation of a lake.

One year later a similar event occurred in the Rio Purmamarca basin; approximately 2.5 million cubic meters of debris dammed the Rio Grande causing one victim, serious damages to infrastructure such as road and bridges and the burial of several $\mathrm{km}$ of railway track. A deposition area of about $200 \mathrm{~m} \times 3000 \mathrm{~m}$, with an average thickness of 4-5 m, was mapped after the event.

Concerning debris flow phenomena, the most evident landform within the Rio Grande Valley is the huge fan of Arroyo del Medio, located between Leon and Volcan, at altitudes ranging from 1600 and $2000 \mathrm{~m}$. Its area is about $9 \mathrm{~km}^{2}$, creating a morphological step of more than $300 \mathrm{~m}$ (Harrington, 1946). The Arroyo del Medio rises at an altitude of $4300 \mathrm{~m}$ and, after more than $10 \mathrm{~km}$, flows into the Rio Grande at an altitude of $2000 \mathrm{~m}$ (Gonzales et al., 1987). 
The debris flow source area is a large and semicircular deep incision located at the foot of Chani Chico $(6200 \mathrm{~m})$, and is characterized by large differences in heights (between 4300 and $2900 \mathrm{~m}$ ), and steep slope (about $40^{\circ}$ ). The flows initiated in this area involve the thick Pleistocenic deposits (Spalletti, 1968). The channel is cut into older deposits and it is up to $50 \mathrm{~m}$ deep in the upper part, while downslope the depth is in the order of $10 \mathrm{~m}$.

The accumulation zone is $8 \mathrm{~km}$ wide, with an average slope of $5^{\circ}$. The granulometry of the deposits is quite varying with respect to different phenomena (Monteverde and Kittl, 1946).

The fan dammed the Rio Grande several times, as documented by the lacustrine deposits located upstream close to the village of Volcan. These clayey and silty deposits are presently cut by the river forming a canyon up to $30 \mathrm{~m}$ deep (Cencetti et al., 2004).

In this area, a huge debris flow occurred during the summer season of 1945 caused the blockage of the Rio Grande and the formation of a lake which flooded the village damaging all the houses and the railway station. After this event it was decided to blast a new epigenetic river bed into the bedrock. Unfortunately the effects of the new hydraulic conditions were not calculated, and thus evident processes of retrogressive erosion, that still continue today, were triggered. This is really unusual, as these are the only active erosion processes in the Quebrada de Humahuaca where mainly depositional processes take place.

In 1984 and 1985 several debris flow phenomena occurred in the Arroyo del Medio catchment as well. In particular, the event of February 1985 caused the complete destruction of a railway bridge and the interruption of the N. R. n. 9 . More than $4 \mathrm{~m}$ thick deposits covered a large area with up to 10 cubic meters blocks. A volume of about 2.4 million cubic meters was estimated. Following these events the National Road was shifted to the fan apex and the Railway "General Belgrano" was completely abandoned some years later.

These phenomena, together with hyperconcentrated flow processes, have deposited a huge volume of sediments in the Rio Grande valley, hindering the normal flow of the river and posing subsequent risky condition for the villages located along the river.

In this framework, the N. R. n. 9 and the villages have to be considered now the main vulnerable elements. The road is threatened either by landslide and debris flow phenomena or by river erosion since it runs close to the river bed. As already mentioned, it was rebuilt several times due to overflooding and erosion processes. But the new route is now affected by landslides, mainly caused by the undercutting of slopes. Generally these landslides are usual shallow and the involved volume is of the order of thousands of cubic meters; nevertheless they cause serious problems for the traffic and for the safety of population with risk conditions that are anyway not acceptable, because of the strategic importance of the road (Fig. 3).

\section{Integrated methodological approach to mitigate the risk}

The Quebrada de Humahuaca is characterized by a huge volume of highly movable debris, causing different typologies of mass movements namely debris flows, slides and falls. In particular, debris flow phenomena have great impact on infrastructures and agricultural activities thus reducing the chances of future development of the area. The valley has provided a natural route for people to travel from the time of hunters and gatherers right to the present day. For this reason it has been included in the UNESCO Word Heritage since 2003 with to the following requests: "to submit to the World Heritage Centre the final management plan and encourage the State Party to carry out an environmental assessment of the proposed flood defence project in order to gauge its impact on the outstanding universal value of the Valley".

In this framework, a mitigation strategy aimed at avoiding potential damages should be implemented in order to preserve the natural condition of such a fragile environment, even if it seems quite complex because of the extent of the area to investigate and because of the close relationship between natural and socio-economic environment.

Given this situation two different needs have to be guaranteed:

- to preserve the landscape as it is without any human intervention;

- to protect the populations and the human activities in order to provide them future chances of development.

An in-depth study of the entire area is not available at present, therefore an integrated and multidisciplinary investigation plan is going to be set up. The research activity should include geological and geomorphological investigations as well as archaeological and historical surveys. Moreover, social and economical aspects have to be considered in order to assess the impact of defence measures on the urban and anthropic environment.

It is not convenient, as it happens nowadays, to design countermeasures for single phenomena without considering all the aspects of the whole geomorphological evolution of the valley. A comprehensive "plan of actions" has to take into account the possibility to reduce the deposition of debris flow materials in the Rio Grande River bed, trapping it along the tributaries. In this way the magnitude of the depositional processes as well as the disequilibrium in the hydrodynamics of the Rio Grande could be reduced.

The slope failures pose serious problems mainly along the N. R. n. 9. More than $100 \mathrm{~km}$ of road is affected by rotational slide and rock fall. This was not considered when the new route of the road was designed, shifting it upslope to avoid flooding phenomena but posing it to landslide hazard. An in-depth evaluation on the more suitable typology of retaining structures has to be done since those located along 

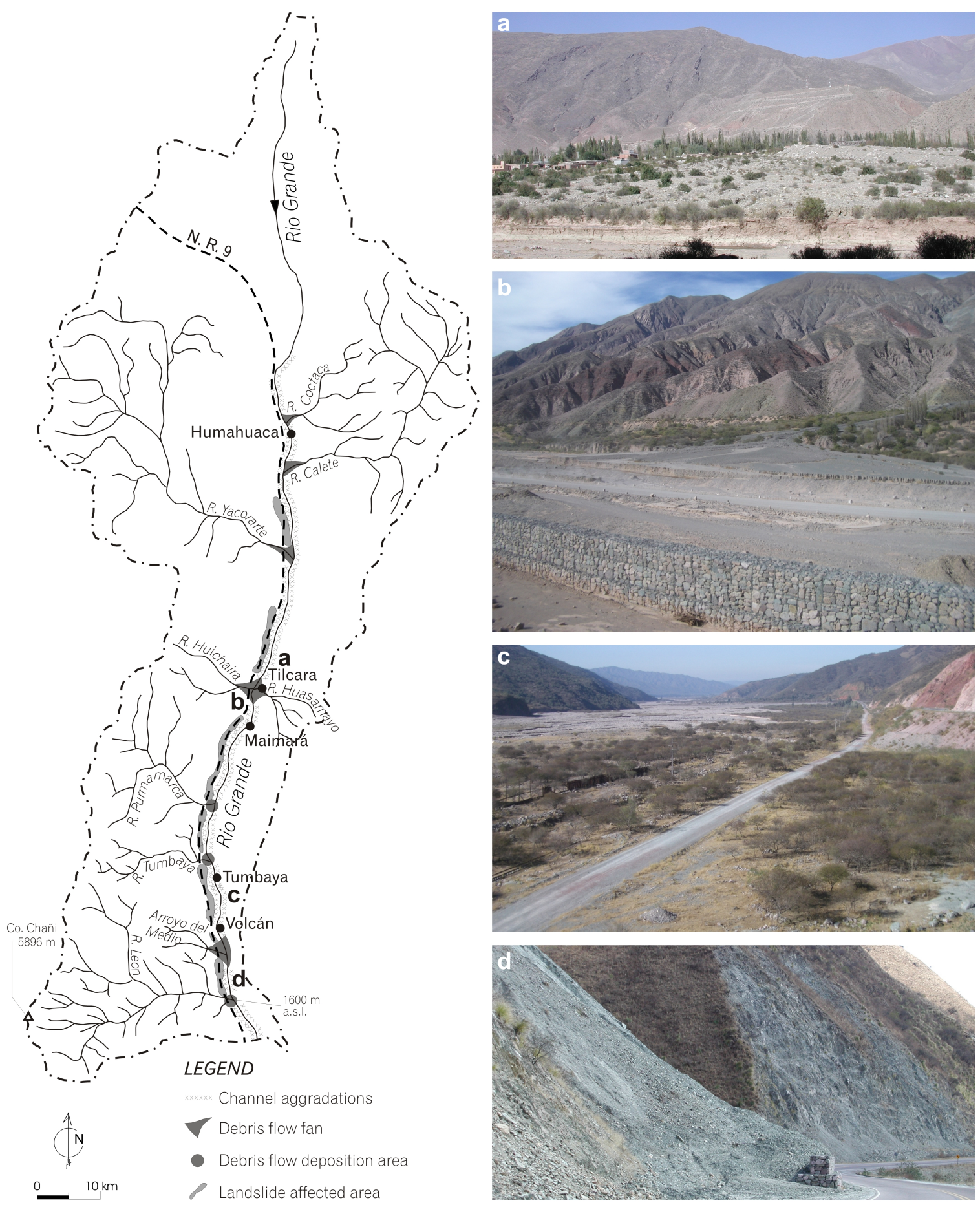

Fig. 3. Quebrada de Humahuaca watershed. The main tributaries and villages along the valley are indicated. (a) A detail of Rio Huasamayo alluvial fan, where Tilcara village is located. The village is permanently threatened by the debris flow phenomena. (b) Quebrada de Trancas, close to Maimarà village. At the confluence with Rio Grande, the alluvial fan generation, due to the recurrent debris flow phenomena, causes the progressive deviation of the Rio Grande riverbed, which, in turn, tends to erode the right river bank. It was necessary to set up a series of gabions in order to protect the N. R. n. 9 Panamericana. (c) Rio Grande riverbed, between Timbaya and Volcan. Due to the alluvial aggradation, the Ferrocaril General Belgrano and the old path of Ruta Nacional were abandoned in 1992. The new road has been rebuilt upslope. (d) n. 9 new route is under a continuous maintenance, due to the frequent debris slides triggering by undercutting processes. 
the road show great differences either in terms of efficiency or environmental impact.

For all these reasons a multidisciplinary team including geologists, geomorphologists, sociologists, archaeologists, landscape architects, human geographers has been appointed for providing a comprehensive study of all the aspects related to the interaction between environment and human settlements. The main aims are to better understand the geomorphologic processes and the socio-economic development in order to design a sustainable mitigation plan. Special attention will be paid to develop tools and methods to increase the public awareness on landslide hazard and to built a resilient community in such a disaster-prone area. This multidisciplinary approach to the slope instability problems of the Quebrada de Humahuaca should bridge the gap between the necessity of preservation and the request of safety, keeping in mind the recommendation of UNESCO.

Acknowledgements. The work presented in this paper was carried out with funding from National Research Council of Italy, International short mobility Program for scientist/researchers from Italian and Foreign Institutions, grant number 0030469/2006.

Edited by: P. Fabian

Reviewed by: two anonymous referees

\section{References}

Amegual, R. and Zanettini, J. C.: Geologia de la quebrada de Humahuaca entre Uquia y Purmamarca (provincia de Jujuy), Revista de la Asociacion Argentina, 29(I), 30-40, 1974.

Cencetti, C., Rivelli, F. R., and Tacconi, P.: Le colate detritiche nell'Arroyo del Medio (Provincia di Jujuy, Argentina nordoccidentale), Proc. of "INTERPRAEVENT 2004" (Riva del Garda, Trento, 24-28 maggio 2004), 1(III), 45-56, 2004.
Cencetti, C., Rivelli, F. R., Tacconi, P., and Viglione, F.: La Quebrada de Humahuaca (Bacino del Rio Grande de Jujuy, Argentina nord-occidentale): caratteristiche di un bacino di ambiente andino, L'Universo, 4, 496-514, 2001.

Chayle, W. and Aguero, P.: Caracteristicas de la remocion en masa en la Cuenca del Rio Grande (quebrada de Humahuaca, Jujuy), Revista del Instituto de Geologia y Mineria, San Salvador de Jujuy, Universidad Nacional de Jujuy, 7, 24-31, 1987.

Gonzales Diaz, E. and Fauque, L. E.: Proveniencia del material componental del torrente de barro de "El Volcan", Quebrada de Humahuaca (Jujuy), Repubblica Argentina, Proc. of Decimo Congreso Geologico Argentino, San Miguel de Tucuman, III, 309-312, 1987.

Harrington, H. J.: Las corrientes de barro (mud flow) del "El Volcan" Quebrada de Humahuaca, Jujuy, Asoc. Geol. Arg. Rev., 1(2), 149-165, 1946.

Mon, R. and Salfity, J. A.: Tectonic evolution of the Andes of Northern Argentina, in: Petroleum basins of South America, edited by: Tankard, A. J., Suarez, R. S., and Welsink, H. J., American Association of petroleum Geologist Memoir, 62, 269-283, 1995.

Monteverde, A. and Kittl, E.: Avalancha "El Volcan", Trabajo, 46, 891-956, 1946.

Ramos, V. A., Turic, M. A., and Zuzek, A. B.: Geologia de las Quebradas de Huichara-Pocoya, Purmamarca y Tumbaya Grande en la Margen Derecha de la Quebrada de Humahuaca (provincia de Jujuy), revista de la Asociacion Geologica Argentina, 22(3), 209-221, 1967.

Spalletti, L. A.: Sedimentologia de los cenoglomerados de Volcan. Provincia de Jujuy. Revista del Museo de La Plata, Universidad Nacional de La Plata, 66(VIII), 137-152. 1968.

Turner, J. C. M.: The Andes of Northwestern Argentina, Geol. Rundsch., 59(3), 1028-1063, 1970. 